\title{
Analysis Of Maternal Risk Factor On Stunting In Children In Palembang City
}

\author{
Pariyana $^{1 *}$, Iche Andriyani Liberty ${ }^{1}$, Muhammad Aziz ${ }^{1}$, Mariana ${ }^{1}$, \\ Machlery.AP ${ }^{2}$, Kevin.S ${ }^{2}$ \\ 1. Teacher Department of Public Health Sciences-Community Medicine \\ Faculty of Medicine, Sriwijaya University \\ 2. Medical Profession Program, Faculty of medicine Sriwijaya University \\ * Corresponding Author: \\ Email: pariana@fk.unsri.ac.id
}

\begin{abstract}
.
The incidence of stunting is one of the sustainable development goals target. To achieve it, an intervention that is right and significant and in accordance with the priority of stunting risk factors. The priority of risk factors is influenced by many things in different places. Thus, this research is the key as a strategy in identifying priority factors as a prevention strategy against stunting toddlers in Palembang. This research is an analytical observational research with case control approach. The samples were collected using purposive sampling techniques and 170 research subjects were obtained. The data was collected from Health Centre of Palembang City by measuring the height according to the age of the toddlers and carried out interviews with the toddler's mother. There results were analysed using Chi-square statistical tests. The analysis results obtained which had a meaningful relation with stunting incidence are maternal age, maternal work, maternal body height, maternal body weight, history of anemia during pregnancy, number of birth, pregnancy gap factor, history of iron or folate supplement consumption history, number of ANC visits, history of infectious diseases during pregnancy, and exclusive breastfeeding. The most dominant risk factors in sequence the chances of stunting children are the number of children more than one by 12 times, anemia during pregnancy by 9 times, mothers who have a high risk age has 7 times, the mother's height is not ideal by 6 times, the distance of pregnancy is equal to or less than 24 months by 4 times, an ANC visit is less than 4 times the chance of 4 times, do not give exclusive breast milk by 4 times, mothers who work outside the house by 3 times, do not consume iron or folate supplements by 3 times.
\end{abstract}

Keywords: Stunting, Toddler, Maternal risk

\section{INTRODUCTION}

Stunting is one of the target for sustainable development goals that was included as the $2^{\text {nd }}$ goal in eliminating hunger and all forms of malnutrition by 2030 and achieving food safety. The target was set to reduce $40 \%$ of stunting rate by 2025 [1]. The occurrence of short toddlers or commonly referred as stunting is one of the nutritional problems experienced by toddlers in the world today. In the year 2017, $22.2 \%$ or about 150.8 million toddlers in the world affected by stunting. However, the 
percentage of stunting has decreased when compared with the stunting figure in the year 2000 which is $32.6 \%$ [2].

The prevalence data of stunting toddlers collected by World Health Organization (WHO) showed that Indonesia is the third country with the highest prevalence in Southeast Asia / South-East Asia Regional (SEAR). The average prevalence of stunting toddlers in Indonesia in 2005-2017 was 36.4\% and in the year 2018, the prevalence of short and very short toddlers was 29.9\% [3,4]. The results of Basic Health Research (Riskesdas) in the year 2007 showed the prevalence of short toddlers in Indonesia as much as $36.8 \%$. In the year 2010, there was a slight decrease to $35.6 \%$. However, the prevalence of short toddlers increased again in 2013 to $37.2 \%$ and in 2018 the prevalence of short and very short toddlers was $30.8 \%$ [4].

Maternal health and nutrition conditions before and during pregnancy and after childbirth affects the fetal growth and risk of stunting. Other factors in the mother that affects are the body posture of the mother (short), the distance of pregnancy is too short, the mother who is still a teenager, as well as the intake of nutrients that are lacking during pregnancy. According to Regulation of the Ministry of Health No. 97 of 2014 concerning Health Services Period before Pregnancy, Pregnancy, Childbirth, and Post-Childbirth Period, Implementation of Contraceptive Services, and Sexual Health Services, factors that aggravate the condition of pregnant women are either too young or too old, frequent child birth, and short birth distance. Mothers who are too young (under 20 years old) are at risk of giving birth to babies with low birth weight (BBLR). BBLR babies affects about $20 \%$ of stunting [5].

Research in Nepal shows that babies with low birth weight have a higher risk of stunting [6]. The length at birth of a baby is also associated with the incidence of stunting. Research in Kendal shows that babies with short birth length are at high risk of stunting in toddlers [7]. Another factor associated with stunting is exclusive breast milk intake in toddlers. Wherelse, Research in Southern Ethiopia proves that toddlers who do not get exclusive breast milk for 6 months are at high risk of stunting [8]. Previous cohort studies have shown that there is a significant association between maternal factors (maternal anthropometrics during pregnancy and lactation, iron intake during pregnancy, maternal haemoglobin $(\mathrm{Hb})$ and ferritin levels during pregnancy as well as the socioeconomic state of the mother's family) towards the risk of stunting when the toddler is 3 years old [9]. In addition, Nisardkk (2016) also explained that non-exclusive breast milk patterns lead to an increase in stunting events in Pakistan. This indicates that the baby's period of 6 months during breastfeeding also affects the growth of the child. Based on the background above, early screening of stunting in children is required by examining maternal factors.

\section{METHODS}

The research conducted was an observational analytical research with case control design. Groups of children at risk of stunting are in case groups and groups of children 
are not at risk of stunting are in control group. The population of this study is all mothers who have children under five years old in Palembang. The sample of this study consisted of case and control. The case group of this study was mothers with stunting children and control groups are mothers with children not stunting (normal) who meet the criteria of inclusion and exclusion, and were selected as research subjects. The variables tied to this study are child body height and age. Free variables are maternal factors (maternal age, education level, occupation, income, maternal height, BMI, history of anemia in pregnancy, number of births, gestational distance, gestational age, gestational body weight, child birth weight, exclusive breastfeeding, consumption of iron and folate supplements during pregnancy, ANC visits, and history of infectious diseases). The data were collected using questionnaires, namely primary data collection, which is the collection of data directly from the results of interviews with respondents. Measurement of body height according to the age of the child and direct interview with the mother of the toddler. The data for the height of children by age is adjusted to the high curve to the age of the World Health Organization (WHO) standard and classified into normal categories (Z-Score $<-1$ SD to $>2$ SD) and stunting (Z-Score <-2 SD). ${ }^{10}$ The data obtained will be analyzed univariate and bivariate. Univariate analysis was used to determine the frequency of maternal factors and to determine the distribution of maternal factors on the samples studied. Bivariate analysis apply chi square test so that it can determine the significance value (p) with a degree of significance $(\alpha)$ of 0.05 .

\section{RESULT AND DISCUSSION}

The research sample was obtained from Health Center of Palembang City by measuring height according to the age of toddlers in the Working Area of Palembang City Health Center in August 2020. Sample taken using purposive sampling technique and were obtained 170 mothers consisted of 85 case groups and 85 control groups. The results of this study are presented in the form of tabulation, narrative and analysis.

\section{Univariate Analysis}

\section{Characteristics of Toddlers}

Distribution according to age for case group and control group, where it was found that age range case group is 24 - 35 months group which is $68.2 \%$ while in control group is $55.3 \%$. The distribution frequency of gender in case groups and control groups where the case and control group had the most female compared to men. There are many stunting incidents found in women with a percentage of $54.1 \%$. Weight is categorized based on normal birth weight and low birth weight (BBLR) where in the case and control group is the birth weight of a normal child. There is a $20 \%$ proportion of stunting incidents in BBLR children. This percentage is smaller than normal children who experience stunting by $80 \%$. From the case groups and 
control groups, the body length for the children most born in the short category. The percentage of children who have a short birth length is stunting by $63.5 \%$.

\section{Maternal Factor Distribution}

Distribution of frequency sample based on maternal age, majority of mothers have an ideal age when pregnant in both control group and case group, majority of mothers have formal education in case group or control group. Housewives has the highest proportion in the control group at 58.8\%. Meanwhile, in the case group, the proportion of mothers working outside is $69.4 \%$. The proportion of mothers with monthly income is more than regional minimum wage at most in both groups. The percentage of monthly revenue below the regional minimum wage rate is $28 \%$, which is more than the control group. The proportion of mothers who had a BMI with the category was not ideal in both groups. The percentage of mothers having an IMT was not ideal in the case group is $64.7 \%$, where the percentage is smaller than the control group. The mother's height was ideal in both groups. It found that the proportion of mothers with an ideal height was $32 \%$, which is more than the control group.

Mothers who did not experience a history of anemia during pregnancy was most likely in both groups. The percentage of mothers who experienced anemia in the case group was $32.9 \%$, which is greater than the control group. The distribution frequency of the number of children that the mother had was the most in the second group. The percentage of mothers who had more than one child in the case group was $96.5 \%$, which is higher than the control group. Pregnancy distance $>24$ months most common in both groups. The percentage of mothers who had a distance $\leq 24$ months was $14.1 \%$, which is lesser than the control group. Mothers who took iron or folic acid supplements during pregnancy were higher in the control group compared to case group. The percentage of mothers who did not consume iron or folate supplements was $69.4 \%$, which is greater than the control group. The proportion of an ANC 4 times or more during pregnancy was highest in the control group. The percentage of an ANC was less than 4 times in the case group of $62.4 \%$, which is much higher than the control group. The proportion of mothers with a full gestational age is the most in both groups. The percentage of mothers who were pregnant with short gestational age in the case group was $21.2 \%$, which is lesser than the control group. Mothers who don't have a history of high infection were more in both groups. The percentage of mothers who experienced infectious diseases in the case group was $17.6 \%$. While in the control group there were no mothers with a history of infectious diseases during pregnancy. The highest proportion of children given exclusive breast milk was found in both groups. The percentage of mothers who did not give exclusive breast milk in the case group was $40 \%$, of which this percentage was greater than the control group.

\section{Bivariate Analysis}

This analysis is done by combining two category variables into a cross tabulation table, which can be found in Table 1 and table 2. Characteristic factors of 
the child (gender, birth weight and birth length) while maternal risk factors (maternal age during pregnancy, maternal education status, maternal work, maternal height, maternal BMI, history of anemia, amount of child birth, pregnancy gap, consumption of iron or folate supplements, ANC examination, gestational age, history of infectious diseases, and exclusive breast milk with dependent variables $(\mathrm{TB} / \mathrm{U})$. In this study there was a control group namely normal children and case groups namely stunted children. The results of bivariate analysis can be seen in Table 1 and Table 2.

Table 1. Child Factors towards Stunting Incident in Palembang

\begin{tabular}{|c|c|c|c|c|}
\hline \multirow[b]{2}{*}{ Child Factors } & \multicolumn{2}{|c|}{$\mathrm{H} / \mathrm{A}$} & \multirow[b]{2}{*}{ p-Value } & \multirow[b]{2}{*}{ OR } \\
\hline & $\begin{array}{c}\text { Stunting } \\
\mathrm{n}(\%)\end{array}$ & $\frac{\text { Normal }}{\mathrm{n}(\%)}$ & & \\
\hline \multicolumn{5}{|l|}{ Child birth weight } \\
\hline Low birth weight & $68(80)$ & $70(82,4)$ & \multirow{2}{*}{0,695} & \multirow{2}{*}{0,857} \\
\hline Normal & $17(20,0)$ & $15(17,6)$ & & \\
\hline \multicolumn{5}{|l|}{ Birth length } \\
\hline Short & $54(63,5)$ & $55(64,7)$ & \multirow[t]{2}{*}{0,873} & \multirow[t]{2}{*}{0,950} \\
\hline Normal & $31(36,5)$ & $30(35,3)$ & & \\
\hline Gender & & & \multirow{3}{*}{0,645} & \multirow{3}{*}{0,868} \\
\hline Boy & $39(45,9)$ & $42(50,6)$ & & \\
\hline Girl & $46(54,1)$ & $43(50,6)$ & & \\
\hline
\end{tabular}

Table 2. Relationship of Maternal Factors to the Incident of Stunting in Palembang

\begin{tabular}{|c|c|c|c|c|}
\hline \multirow{3}{*}{ Maternal Factors } & \multicolumn{2}{|c|}{$\mathrm{H} / \mathrm{A}$} & \multirow{3}{*}{ p-Value } & \multirow{3}{*}{ OR } \\
\hline & Stunting & Normal & & \\
\hline & $\mathrm{n}(\%)$ & $\mathrm{n}(\%)$ & & \\
\hline \multicolumn{5}{|l|}{ Mother's Age } \\
\hline High risk & $7(8,2)$ & $1(1,2)$ & \multirow{2}{*}{0,030} & \multirow{2}{*}{7,538} \\
\hline Ideal & $78(91,8)$ & $84(98,8)$ & & \\
\hline \multicolumn{5}{|l|}{ Mother's Last Education } \\
\hline Informal education & $18(21,2)$ & $12(14,1)$ & \multirow{2}{*}{0,227} & \multirow{2}{*}{1,634} \\
\hline Formal education & $67(78,8)$ & $73(85,9)$ & & \\
\hline \multicolumn{5}{|l|}{ Mother's work } \\
\hline Work & $59(69,4)$ & $35(41,2)$ & \multirow{2}{*}{0,000} & \multirow{2}{*}{3,242} \\
\hline Housewives & $26(30,6)$ & $50(58,8)$ & & \\
\hline \multicolumn{5}{|l|}{ Income } \\
\hline$>$ Regional minimum wage & $28(32,9)$ & $17(20,2)$ & \multirow{2}{*}{0,056} & \multirow{2}{*}{1,965} \\
\hline$<$ Regional minimum wage & $57(67,1)$ & $68(79,8)$ & & \\
\hline \multicolumn{5}{|l|}{ BMI } \\
\hline Not Ideal & $58(68,2)$ & $55(64,7)$ & \multirow{2}{*}{0,626} & \multirow{2}{*}{0,853} \\
\hline Ideal & $27(31,8)$ & $30(35,3)$ & & \\
\hline
\end{tabular}




\begin{tabular}{|c|c|c|c|c|}
\hline \multicolumn{5}{|c|}{ Mother's Height during pregnancy } \\
\hline Short & $28(32,9)$ & $6(7,1)$ & \multirow{2}{*}{0,000} & \multirow{2}{*}{6,468} \\
\hline Ideal & $57(67,1)$ & $79(92,9)$ & & \\
\hline \multicolumn{5}{|l|}{ History of anemia } \\
\hline Yes & $28(32,9)$ & $4(4,7)$ & \multirow{2}{*}{0,000} & \multirow{2}{*}{9,947} \\
\hline No & $57(67,1)$ & $81(95,3)$ & & \\
\hline \multicolumn{5}{|l|}{ Amount of child birth } \\
\hline Two or more & $58(68,2)$ & $82(96,5)$ & \multirow{2}{*}{0,000} & \multirow{2}{*}{12,724} \\
\hline First & $27(31,8)$ & $3(87,6)$ & & \\
\hline \multicolumn{5}{|l|}{ Pregnancy gap } \\
\hline$\leq 24$ & $78(91,8)$ & $59(69,4)$ & \multirow{2}{*}{0,000} & \multirow{2}{*}{4,910} \\
\hline$>24$ & $7(8,2)$ & $26(30,6)$ & & \\
\hline
\end{tabular}

Consumption of Iron or Folic acid

Supplements

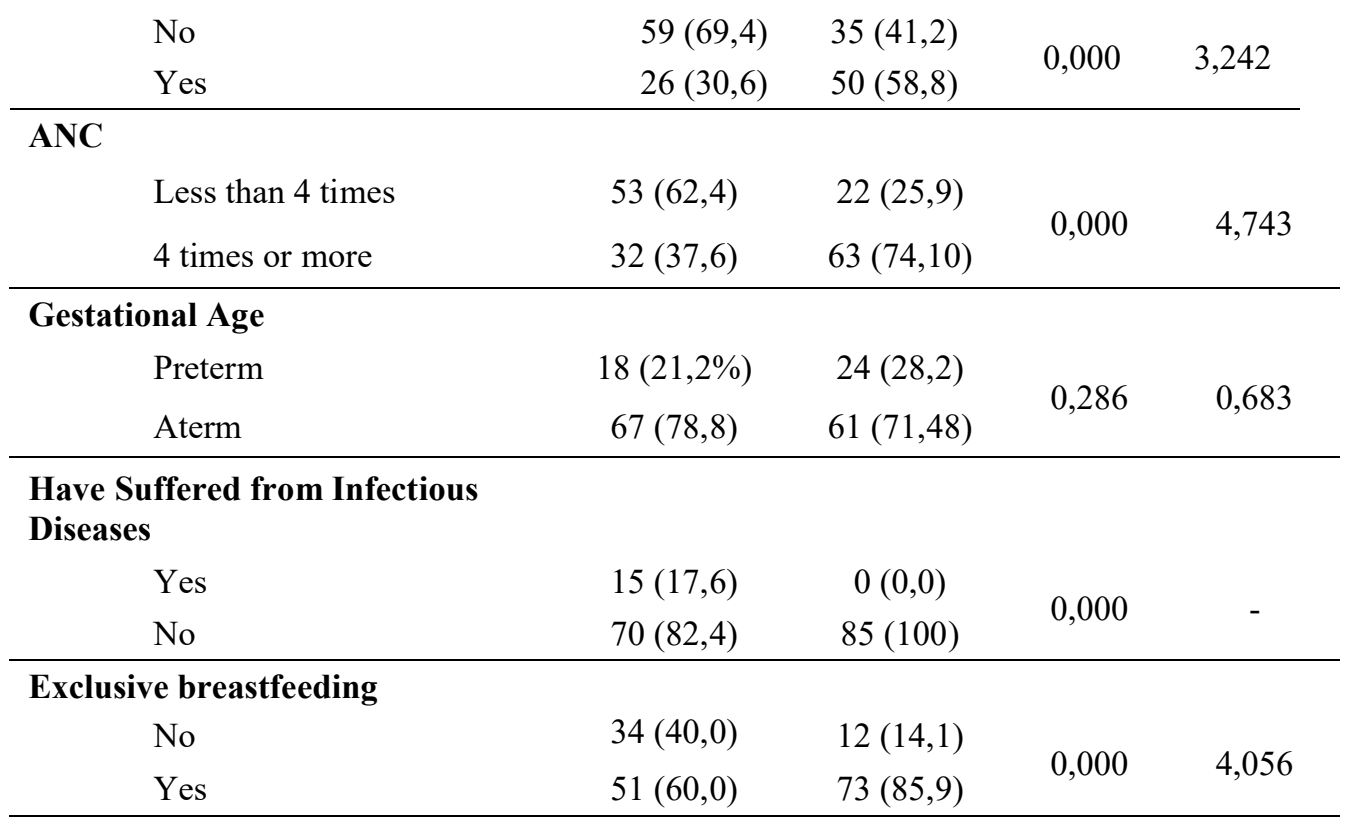

Based on Table 1. The relationship between child characteristics (gender, birth length and birth weight) did not have a significant relationship with the incidence of stunting ( $>0.05$ ). Whereas in Table 2, the relationship between maternal factors and the incidence of stunting shows that there is a significant relationship between maternal age, maternal occupation, maternal height during pregnancy, history of anemia, amount of child birth, pregnancy gap, consumption of iron or folic acid supplements, ANC, history of infection and administration. Exclusive breastfeeding against the incidence of stunted children $\mathrm{p}$ value $<0.05$. And there is no significant relationship between 
maternal education status, monthly income, BMI and gestational age on the incidence of stunting with a value of $\mathrm{p}>0.05$.

Based on the odds ratio value, it is concluded that sequentially the chance for the incidence of stunted children is 12 times the number of children, anemia during pregnancy is 9 times, mothers who have a high age risk have 7 times, the mother's height is not ideal for 6 times, pregnancy gap equal to or less than 24 months by 4 times, ANC visits of less than 4 times have a chance of 4 times, not giving exclusive breastfeeding 4 times, mothers who work outside the home by 3 times, do not take as much iron or folate supplements by 3 times.

The development of a child really determines how their life will be in the future, especially at the first 5 years of life. Based on the research conducted, out of 170 children who were divided into case groups and control groups showed that the most children age range in the group was the 24 - 35 months age group, mostly $68.2 \%$ while in the control group it was $55.3 \%$. Based on gender, the proportion of girls were more than boys in the two groups, the number of girls was 46 children $(54.4 \%)$ in the case group and 43 children (50.6) in the control group. The results of this study differ from the data from Riskesdas (2018), regarding the characteristics of under-fives being weighed, where there are more boys than girls. In addition, normal birth weight, short birth length, ideal maternal age, the latest formal mother's education, maternal income $<\mathrm{IMR}$, not ideal maternal BMI, ideal maternal height, no history of anemia and infection, total child birth $>1$, gestation gap $>24$ months, and full term of gestation age had the largest proportion in both the case and control groups. There were differences in the variables of maternal occupation, mothers who consumed iron and folic acid supplements, the number of ANC, and exclusive breastfeeding in the two groups. In the case group, most mothers were working, the mother did not consume iron and folic acid supplements, the number of ANC was $<4$ times, and the child was not exclusively breastfed. In contrast, mothers who do not work, women who consume iron and folic acid supplements, the number of ANC $>4$ times, and children who are exclusively breastfed are in the control group [4].

The results of bivariate analysis, based on birth weight and birth height, obtained $p$ value $>0.05$, which means there is no relationship between birth weight and birth length with the incidence of stunting. This result is different from the research by Mangala et al. (2018), it was found that birth weight ( $p$ 0.001) and birth length ( $p$ 0.001 ) shows that there is a relationship between birth weight and birth length with the incidence of stunting [10]. Rahayu (2011) research states that there is a correlation between birth body weight and birth body length with the incidence of stunting. Birth body weight is a factor that plays a big role in the growth of children in the future. Children with low birth body weight (under 2,500 grams) tend to have a higher risk of malnutrition, infection, and degenerative disease [11]. Diseases that arise will affect the development of children and in the future will increase morbidity [10]. In addition, this may be caused by genetic factors or poor nutritional status of the mother during 
pregnancy [12]. There is a significant relationship between exclusive breastfeeding and the incidence of stunting, the $\mathrm{p}$ value is 0.000 and the OR value is 4.056 , which means that the risk of stunting in children who are not exclusively breastfed is 4 times. These results are consistent with the research of Mangala et al. (2018), it was found that there was a significant relationship between exclusive breastfeeding and the incidence of stunting, value (p 0.005) [10]. In contrast to the research of Sumiaty et al (2017) states that there is no relationship between exclusive breastfeeding and the incidence of stunting with a $\mathrm{p}$ value of 0.985 [13]. Breast milk is an important food intake for babies during the first six months of life. WHO and the Indonesian Ministry of Health recommended exclusive breastfeeding in the first 6 months of birth, because breast milk contains sufficient nutrition for babies and has many advantages over formula milk that provides adequate nutrition such as boosting the body's immune system, contributing to the development of brain function and good for growth and development of a baby. Babies who are not exclusively breastfed tend to have an increased risk of stunting. According to WHO regarding child stunting, it states that inadequate breastfeeding, such as not exclusive breastfeeding, delayed initiation, or early termination of breastfeeding is significantly associated with stunting cases [14].

Based on the mother's latest education and income, the $\mathrm{p}$ value is $>0.05$, which means that there is no significant relationship between mother's last education and income with the incidence of stunting. Meanwhile, based on maternal occupation, there is a significant relationship between maternal work and the incidence of stunting with a $\mathrm{p}$ value of 0.000 with an OR value of 3.242, which means that mothers who works have a 3 times greater risk of children being stunted than mothers who do not work and stays as housewifes. Sumiaty's research (2017) shows that there is no relationship between education and the incidence of stunting with a $p$ value of 0.318 [13]. Khairani's research (2019) found that there was no relationship between education and income with the incidence of stunting, $p$ value $>0.05$ [15]. Wanimbo's research (2020) shows that mothers who do not work tend to have children who are not stunted [16].

Factors affecting nutritional status include: lack of information, lack of community purchasing power, and parents jobs. Family income is dependent on the parent's work which is used to meet the nutritional needs of the family. Working mothers have less time to care for their children than mothers who do not work, so this will affect the quality of child care and thus affect the child's nutritional status. Mothers who work from morning till evening until they don't have much time to pay attention to the food and nutritional needs for their children [17].

Based on maternal BMI at pregnancy and maternal gestational age, $p$ value> 0.05 means that there is no relationship between maternal BMI during pregnancy and maternal gestational age with the incidence of stunting. There is a significant relationship between maternal age, maternal height at pregnancy, history of anemia, total child birth, pregnancy gap, consumption of iron and folic acid supplements, ANC and history of infection during pregnancy with the incidence of stunting with $p$ value 
$<0.05$. The OR value is 7.538 , which can be interpreted that mothers with high age risk have a chance of 7 times in getting stunted child. OR value of 6.468 , which means the risk of child stunting at a not ideal maternal height is 6 times. The OR value is 9.947 which means that the risk of stunting children in mothers with a history of anemia during pregnancy is 9 times. The OR value is 12.724 which means the risk of stunting children to the mother with a child birth of more than one is 12 times. The OR value is 4,910 , which means that the risk of child stunting with a pregnancy gap of the mother is equal to or less than 24 months by 4 times. The OR value was 3.242, which means that the risk of child stunting in mothers who do not take iron or folate supplements is 3 times. The OR value is 4.743 , which means that the risk of stunting children with $\mathrm{ANC}$ is less than 4 times is 4 times.

In alignment with research by Mangala et al. (2018), it was found that maternal age ( $p$ 0.001), maternal height at pregnancy ( $p$ 0.004), and gestational age ( $p$ 0.365). The results are also in alignment with Sumiaty's (2017) study, it was found that maternal height at pregnancy ( $p$ 0.012), gestational age ( $p$ 0.000) and ANC ( $p 0.001)$. Different results from the research of Mangala et al. (2018) acquired the amount of childbirth ( $\mathrm{p}$ 0.308) [10]. The results of Wanimbo's (2018) study obtained $\mathrm{p}$ value = $0.003(<0.05)$, which means that there is a significant relationship between maternal age and the incidence of stunting. Mothers who are still adolescents ( $<20$ years) if they are pregnant have a higher risk of having stunted offspring than mothers of reproductive age (20-34 years) and are associated with growth failure in infants [16]. Physical growth in adolescent mothers is still ongoing, therefore the reproductive organs have not yet matured. So the risk of conceiving an Intrauterine Growth Restriction (IUGR) fetus and giving birth to a child who is LBW and stunted will increase. In addition, psychologically, the development of a mother's mindset who is still young is not mature enough so the parenting of child nutrition in adolescent mothers is not as good as older mothers $[18,16]$ In the field, there are multiple marriages at a fairly young age. This is related to the understanding or culture of the local community, which is still followed by some people who think that women don't need to pursue higher studies because they will work in the kitchen.

However, the results of this study are inversely proportional to previous studies in Bandar Lampung where there were no significant relationship between maternal age and the incidence of stunting [19,16]. In contrast to the results of Wanimbo's (2018) study, the $\mathrm{p}$ value $=0.303(>0.05)$, which means that there is no relationship between maternal height and the incidence of stunting. Height is influenced by genetic factors so that it can affect fetal growth and organ function. ANC visits that are carried out regularly can detect early pregnancy risks that exist in 18 mothers, especially those related to nutritional problems $[16,20,21]$. 


\section{CONCLUSION}

1. The results of the analysis were found to have a significant relationship with the incidence of stunting, mainly factors such as maternal age, maternal occupation, maternal height, maternal weight, history of anemia during pregnancy, number of child births, pregnancy gap factors, consumption of iron or folate supplement history, number of ANC visits, history of infectious diseases during pregnancy, and exclusive breastfeeding.

2. The most dominant risk factors, respectively, are more than one total number of children is 12 times more than one child, 9 times anemia during pregnancy, 7 times more for higher age mothers, the mother's height is not ideal. 6 times, the pregnancy gap is equal to or less than 24 months by 4 times, ANC visits less than 4 times have a 4 times chance, not giving exclusive breastfeeding 4 times, mothers who work outside is 3 times, not consumption of iron or folate supplements is 3 times.

\section{ACKNOWLEDGMENTS}

Thanks a bunch to students and colleagues who have helped this research activity. Thanks alot to Sriwijaya University for funding the 2020 University Research Grant.

\section{REFERENCES}

[1] Kementerian Perencanaan Pembangunan Nasional (Bapenas) dan United Nations Children's Fund. Laporan Baseline SDG tentang Anak-Anak di Indonesia. 2017.

[2] United Nations International Children's Emergency Fund (Unicef) 2018, Stunting, diakses 2p April 2020.

[3] WHO. 2017. Stunted Growth and Development. Geneva.

[4] Riset Kesehatan Dasar (Riskesdas) (2018). Badan Penelitian dan Pengembangan Kesehatan Kementerian RI tahun 2018. http://www.depkes.go.id/resources/download/infoterkini/materi_rakorpop_2018/Hasil\%20Riskesdas\%202018.pdf - Diakses Juni 2020

[5] Kementerian Kesehatan Republik Indonesia. 2017. Modul Pelatihan Fasilitator Sanitasi Total Berbasis Masyarakat (STBM-Stunting). Kementerian Kesehatan Republik Indonesia.

[6] Paudel, et al. 2012. Risk Factors For Stunting Among Children: A Community Based Case Control Study In Nepal. Kathmandu University Med J. 2012; 10(3): 18-24

[7] Meilyasari F, dan M.Isnawati. 2014. Faktor Risiko Kejadian Stunting Pada Balita Usia 12 Bulan Di Desa Purwokerto Kecamatan Patebon, Kabupaten Kendal. Journal of Nutrition College, Volume 3, Nomor 2.

[8] Fikadu, T., Assegid, S., Dube, L. 2014. Factor associated with stunting among children age 24 to 59 months in Meskan District, Gurage Zone, South Ethiopia: A case-control study. BMC Public Health. 14(800). (http://www.biomedcentral.com/1471-2458/14/800., Diakses pada tanggal 05 Oktober 2020). 
[9] Hanieh, S., Ha, T. T., Simpson, J. A., Thuy, T. T., Khuong, N. C., Thoang, D. D., Biggs, B. A. 2019. Exclusive breast feeding in early infancy reduces the risk of inpatient admission for diarrhea and suspected pneumonia in rural Vietnam: A prospective cohort study Global health. BMC Public Health, 15(1), 1-10. https://doi.org/10.1186/s12889015-2431-9

[10] Mangala AK, dkk. 2018. Risk Factors of Stunting in Children aged 24-59 months. Paediatrica Indonesiana. 58(201;8); 205-12

[11] Rahayu LS, Sofyaningsih M. 2011. Pengaruh BBLR (berat badan lahir rendah) dan pemberian ASI eksklusif terhadap perubahan status stunting pada balita di Kota dan Kabupaten Tangerang Provinsi Banten. In: Seminar Nasional Peran Kesehatan Masyarakat dalam Pencapaian MDG's di Indonesia. p. 160-9.

[12] United Nations Children's Fund and World Health Organization. 2004. Low Birthweight: Country, regional and global estimates. UNICEF. New York; p. 1-31

[13] Sumiaty S, Pont AV dan Sundari S. 2017. Relationship of Mother Factors, Breastfeeding and Stunting Pattern in Central Selawesi. Internasional Journal of Sciences Basic and Applied Research. 35(3); 413-420

[14] Al-Rahmad AH, Miko A, Hadi A. Kajian stunting pada anak balita ditinjau dari pemberian ASI eksklusif, MP-ASI, status imunisasi dan karakteristik keluarga di Kota Banda Aceh. J Kes Ilm Nasuwakes. 2013;6:169-84.

[15] Khairani, M., Sutisna, \& Suyanto, S. 2019. Studi Meta-Analisis Pengaruh Video Pembelajaran Terhadap Hasil Belajar Peserta Didik. Jurnal Biolokus, 2(1), 158-166.

[16] Wanimbo E dan Wartiningsih M. 2018. Hubungan Karakteristik Ibu Dengan Kejadian Stunting Baduta (7-24 Bulan). Jurnal Manajemen Kesehatan Yayasan RS.Dr.Soetomo. 6(1): 83-93

[17] Fauziah dan Sutejo. 2012.Keperawatan Maternitas Kehamilan. Jakarta: Kencana Prenada Media Group.

[18] Stephenson, T. J., dan Schiff, W. J. (2019). Human nutrition science for healthy living (2nd Editio). New York: McGraw-Hill.

[19] Sumardilah, D. S., dan Rahmadi, A. (2019). Risiko Stunting Anak Baduta (7-24 bulan). Jurnal Kesehatan. 10(1); 93. https://doi.org/10.26630/jk.v10i1.1245

[20] Ni'amah, S. 2014. Hubungan Kualitas Pemenuhan Konsumsi Tablet FE dengan Kejadian Anemia pada Ibu Hamil Trimester III. Jurnal Ilmu Kebidanan \& kesehatan. 5 (2) : 1319.

[21] Khoeroh H dan Indriyanti D. 2017. Evaluasi Penatalaksanaan Gizi Balita Stunting di Wilayah Kerja Puskesmas Sirampog. Unnes Journal of Public Health. 6(3). 